\title{
Isolation and characterization of Staphylococcus aureus starvation-induced, stationary-phase mutants defective in survival or recovery
}

\author{
Sean P. Watson, Martin Antonio and Simon J. Foster \\ Author for correspondence: Simon J. Foster. Tel: +44 114222 4411. Fax: +44114272 8697. \\ e-mail: s.foster@sheffield.ac.uk
}

Department of Molecular Biology and

Biotechnology, University of Sheffield, Firth Court, Western Bank, Sheffield S10 2TN, UK

\begin{abstract}
Ten Staphylococcus aureus mutants, defective in the starvation-induced stationary phase of growth were isolated from two independent Tn917-LTV1 transposon insertion libraries and were designated suv as they had apparent survival defects. Seven of these mutants were defective under amino-acidlimiting conditions alone. Two mutants (suv-3 and suv-20) demonstrated lower plating efficiency when starved for glucose, phosphate or amino acids and one mutant (suv-11) had reduced plating efficiency after amino acid or glucose starvation. All of the mutants tested were as resistant to hydrogen peroxide assault as the parent, but six were more sensitive to low pH conditions. All the mutants were physically mapped on the $S$. aureus chromosome using PFGE. Chromosomal DNA flanking the Tn917-LTV1 insertion sites was rescued by cloning into Escherichia coli. DNA sequence analysis resulted in the identification of a number of transposon-disrupted ORFs encoding putative components such as superoxide dismutase (suv-1), haem A synthase (suv-3), a component of the SOS response (suv-9) and hypoxanthine-guanine phosphoribosyltransferase (suv-20). The Tn917-LTV1 insertion created lacZ transcriptional fusions for some of the stationary-phase loci. Expression analysis indicated that suv- 4 was induced at mid-exponential phase, whereas suv-3 and suv-11 were induced at the onset of stationary phase. The possible roles of these suv components in stationary-phase survival or recovery is discussed.
\end{abstract}

Keywords: Staphylococcus aureus, stationary-phase, starvation survival, recovery, insertional mutagenesis

\section{INTRODUCTION}

Staphylococcus aureus is a major human pathogen capable of causing a spectrum of diseases ranging from minor infections such as carbuncles to severe sepsis. Localized infections with $S$. aureus, especially in wounds, are very common because of its ability to survive and persist in a wide range of environments such as mammalian abscesses (Nahmias \& Shulman, 1972) or dry dust (Lidwell \& Lowbury, 1950). The ability to survive outside the host and the difficulty in its eradication has contributed to $S$. aureus being one of the most

Abbreviations: CDM, chemically defined medium; MUG, 4-methylumbelliferyl $\beta$-D-galactoside. important causes of nosocomial infections worldwide (Ayliffe, 1997; Maniatis et al., 1997). The emergence of a new epidemic methicillin-resistant $S$. aureus, designated EMRSA-16, is one of the most intractable problems facing hospital practice today (Communicable Disease Report, 1996). EMRSA-16 is highly transmissible, especially by hand contact and has been implicated in a large number of outbreaks (Communicable Disease Report, 1994). An understanding of how S. aureus is able to survive starvation and other environmental stresses might offer opportunities for improvements in the control of this organism as it cycles from host to terrestrial milieus.

Recently, Watson et al. (1998) showed that carbon limitation, or multiple-nutrient-starvation, are the most 
important stimuli for the development of long-term survival potential in $S$. aureus. Starvation results in decreased cell size and enhanced resistance to acid shock and hydrogen peroxide stress. Long-term survival is dependent on continued protein synthesis and differential expression of proteins has been demonstrated deep into starvation (Watson et al., 1998). These observations are in concordance with previous studies on the starvation-induced stationary-phase survival kinetics of other non-spore-forming bacterial species, including Micrococcus luteus, Vibrio sp., Sinorhizobium meliloti, Rhizobium leguminosarum bv. phaseoli, Escherichia coli and Salmonella typhimurium (Jenkins et al., 1988; Kaprelyants \& Kell, 1993; Kjelleberg et al., 1993; Matin et al., 1989; O'Neal et al., 1994; Thorne \& Williams, 1997; Uhde et al., 1997). There is no evidence for the formation of a viable but non-culturable state in $S$. aureus during starvation as shown by using flow cytometry (Watson et al., 1998).

Analysis of cellular proteins synthesized during starvation has shown that differential protein synthesis occurs. Proteins are temporally expressed throughout different stages of starvation (Lange \& Hengge-Aronis, 1991; Nystrom, 1995; Nystrom et al., 1990; Reeve et al., 1984; Spector \& Cubitt, 1992; Watson et al., 1998). In E. coli and Sal. typhimurium, expression of some of these starvation-associated proteins is mediated by regulatory components such as RpoS (O'Neal et al., 1994; Lange \& Hengge-Aronis, 1991). RpoS is an alternative sigma factor of RNA polymerase which mediates the expression of genes required for long-term starvation survival. These include genes involved in resistance to environmental stresses, such as oxidation, low $\mathrm{pH}$ and the host environment associated with virulence (Cheville et al., 1996; Nickerson \& Curtiss, 1997; O’Neal et al., 1994; Seymour et al., 1996; Wilmes-Riesenberg et al., 1997). For example, Nickerson \& Curtiss (1997) showed that in Sal. typhimurium, RpoS controls the expression of spv genes during the initial stages of systemic infection.

Recently, Clements \& Foster (1998) have characterized the starvation-recovery mechanism of $S$. aureus and have shown that the addition of either glucose or amino acids alone could not recover cells from glucose-induced starvation. Regrowth occurs only by addition of complex medium or a mixture of amino acids and glucose. The starvation-survival phenotype is quickly lost during recovery to allow cells to resume vegetative growth. This process is temporally regulated and requires differential protein synthesis.

The components required for the development and maintenance of the starvation-induced stationary-phase survival state and recovery in $S$. aureus are unknown. Their identification will allow the elucidation of the survival and recovery mechanisms. Starvation survival and recovery may play an important role in the ability of $S$. aureus to persist inside and outside the host and contribute to its success as a pathogen. This paper describes the identification and characterization of $S$. aureus mutants defective in starvation-induced stationary-phase survival or recovery using transposon mutagenesis.

\section{METHODS}

Bacterial strains. The parental strain used in this study was $S$. aureus 8325-4 (Novick, 1967). S. aureus strains were maintained in Tryptic Soya Broth (TSB) (Oxoid) medium with or without $1 \%(\mathrm{w} / \mathrm{v})$ agar at $37^{\circ} \mathrm{C}$. Antibiotics were added where appropriate. E. coli DH5 $\alpha$ was grown in Luria-Bertani (LB) (Oxoid) medium with or without $1 \%$ agar at $37^{\circ} \mathrm{C}$. E. coli plasmids were selected with $50 \mu \mathrm{g}$ ampicillin $\mathrm{ml}^{-1}$.

S. aureus starvation conditions. $S$. aureus strains were grown in an amino-acid-limiting, chemically defined medium (CDM) (Hussain et al., 1991; Watson et al., 1998). Glucose- and phosphate-limiting CDM were prepared by lowering the glucose concentration from $1 \%(\mathrm{w} / \mathrm{v})$ to $0.1 \%$ and phosphate concentration from $0.18 \mathrm{M}$ to $36 \mathrm{mM}$, respectively. For starvation-induced stationary-phase survival/recovery studies, a $50 \mathrm{ml}$ culture of glucose-, amino-acid- or phosphatelimiting CDM in a $100 \mathrm{ml}$ flask was inoculated from an overnight $\mathrm{CDM}$ agar plate to an $\mathrm{OD}_{600}$ of 0.01 and incubated with shaking ( 250 r.p.m.) at $37^{\circ} \mathrm{C}$ for 18 h. The cultures were then incubated statically at 4,25 or $37^{\circ} \mathrm{C}$. Colony-forming ability was determined by serial dilution of samples in PBS and spreading onto CDM agar (1\% agar). The number of c.f.u. $\mathrm{ml}^{-1}$ was assessed after incubation at $37^{\circ} \mathrm{C}$ for $18 \mathrm{~h}$. All data presented are representative of at least two independent cultures, which showed no more than 10 -fold variability between equivalent time points.

Stress resistance assays. Starved cells were prepared by growth in glucose-limiting CDM as described above and then incubated statically for 4 weeks at $25^{\circ} \mathrm{C}$. The cells were then harvested by centrifugation $(11000 \mathrm{~g}, 5 \mathrm{~min}, \mathrm{RT})$, washed once in PBS by resuspension and centrifugation (as above) and finally resuspended at $5 \times 10^{5}$ c.f.u. $\mathrm{ml}^{-1}$ in PBS.

For hydrogen peroxide treatment, cells were resuspended in PBS containing $7.5 \mathrm{mM}$ hydrogen peroxide and then incubated at $37^{\circ} \mathrm{C}$. Samples $(0.1 \mathrm{ml})$ were withdrawn and diluted in PBS containing $10 \mathrm{mg}$ catalase $\mathrm{ml}^{-1}$ and plated onto CDM agar. For acid treatment, cells were resuspended in acidified glucoselimiting CDM (pH 2) (Watson et al., 1998) and then incubated at $37^{\circ} \mathrm{C}$. Samples $(0.1 \mathrm{ml})$ were withdrawn, diluted in PBS and plated on CDM agar.

Creation of Tn917-LTV1 insertion libraries. Two independent Tn917-LTV1 transposon insertion libraries of $S$. aureus 8325 4 were created using the temperature-sensitive vector pLTV1 (Camilli et al., 1990). The plasmid was introduced into $S$. aureus $8325-4$ by electroporation (Schenk \& Laddaga, 1992) and maintained by growth at $30^{\circ} \mathrm{C}$ in TSB containing $5 \mu \mathrm{g}$ tetracycline $\mathrm{ml}^{-1}$. To create transposon libraries, $S$. aureus $8325-4$ pLTV1 was grown at $37^{\circ} \mathrm{C}$ in $100 \mathrm{ml} \mathrm{TSB}$ (containing $5 \mu \mathrm{g}$ each of erythromycin and tetracycline $\left.\mathrm{ml}^{-1}\right\rangle$ to an $\mathrm{OD}_{600}$ of 1.0 . An aliquot $(5 \mathrm{ml})$ of the culture was harvested by centrifugation $\left(8000 \mathrm{~g}, 5 \mathrm{~min}, 37^{\circ} \mathrm{C}\right)$, resuspended in $100 \mathrm{ml}$ prewarmed $\left(43^{\circ} \mathrm{C}\right.$ ) TSB (containing $5 \mu \mathrm{g}$ erythromycin $\mathrm{ml}^{-1}$ ) and incubated at $43^{\circ} \mathrm{C}$ with shaking (250 r.p.m.) to an $\mathrm{OD}_{600}$ of 1.5 . An aliquot $(5 \mathrm{ml})$ was removed and inoculated into $100 \mathrm{ml} \mathrm{TSB}$ (containing $5 \mu \mathrm{g}$ erythromycin $\mathrm{ml}^{-1}$ ) at $43^{\circ} \mathrm{C}$. The culture was incubated for $18 \mathrm{~h}$ at $43^{\circ} \mathrm{C}$ with shaking (250 r.p.m.) prior to harvesting by centrifugation (as above), resuspension in TSB containing $15 \%(\mathrm{v} / \mathrm{v})$ glycerol, snap freezing and storage at $-70^{\circ} \mathrm{C}$. Both transposon libraries had approximately $5 \times 10^{9}$ c.f.u. $\mathrm{ml}^{-1}$ and greater than $95 \%$ of cells contained transposon insertions. 
Selection of stationary-phase mutants. Aliquots of the transposon libraries were spread onto CDM agar plates to yield approximately 150-200 colonies per plate, after incubation at $37^{\circ} \mathrm{C}$ for $18 \mathrm{~h}$. The colonies were replica-plated onto two $\mathrm{CDM}$ agar plates and again incubated at $37^{\circ} \mathrm{C}$ for $18 \mathrm{~h}$. One CDM plate was incubated at $4{ }^{\circ} \mathrm{C}$ for $21 \mathrm{~d}$ and the other at $25^{\circ} \mathrm{C}$ for $21 \mathrm{~d}$. Our previous studies have shown that S. aureus cells survive appreciably longer at $4{ }^{\circ} \mathrm{C}$ than at $25^{\circ} \mathrm{C}$ in CDM (Watson et al., 1998). As a consequence, the plate stored at $4{ }^{\circ} \mathrm{C}$ was the stock plate and the $25^{\circ} \mathrm{C}$ plate, the selection plate. After $21 \mathrm{~d}$, the selection plate was replicaplated onto a fresh CDM agar plate and incubated at $37^{\circ} \mathrm{C}$ for $18 \mathrm{~h}$. Growth on this plate was then compared with the stock plate. Any colonies absent on the replicate from the selection plate but present on the stock plate were putative stationaryphase survival/recovery mutants (suv). These suv mutants were then picked from the stock plate and re-tested for their survival/recovery ability. To confirm that the transposon insertion was responsible for the observed phenotype, the transposon was transferred into the parental S. aureus 8325-4 background using the general transducing phage $\phi 11$ as described by Mani et al. (1993). The transductants were tested for erythromycin resistance and the stationary-phase survival/recovery defect.

Molecular biological methods. All molecular biological methods were performed as described by Sambrook $e t$ al. (1989). Chromosomal DNA from S. aureus was isolated using a Qiagen 100/G kit according to the manufacturer's instructions except that bacterial cells were lysed by lysostaphin (Sigma; $200 \mu \mathrm{g} \mathrm{ml}^{-1}$ ) at $37^{\circ} \mathrm{C}$ for $30 \mathrm{~min}$.

Rescue of chromosomal DNA flanking Tn917 insertion sites. The Tn917-LTV1 insertions carry a multiple cloning site, the ColE1 origin of replication and an ampicillin resistance gene (Camilli et al., 1990). Chromosomal DNA from the suv mutants was digested with either XbaI or EcoRI. Both these enzymes restrict the DNA within the transposon multiple cloning site and the nearest restriction site in the chromosomal DNA (Youngman, 1990). The digested DNA fragments were purified using the Geneclean II kit, according to the manufacturer's instructions. The DNA fragments were self-ligated at $1 \mu \mathrm{g} \mathrm{ml}^{-1}$ to generate a plasmid containing a fragment of chromosomal DNA flanking the transposon, ColE1 origin of replication and the ampicillin resistance gene. The latter two elements are Tn917-LTV1-derived. These plasmids were transformed into $E$. coli $\mathrm{DH} 5 \alpha$ and clones selected for ampicillin resistance.

Nucleotide sequence analysis. Rescued chromosomal DNA in the Tn917-LTV1-derived plasmids was sequenced using the Taq DyeDeoxy Terminator Cycle Sequencing Kit and the ABI 373A DNA sequencer according to the manufacturer's instructions (Applied Biosystems). A 25 bp oligonucleotide ( $5^{\prime}$ CTCACAATAGAGAGATGTCACCGTC) complementary to the region upstream of the lacZ-proximal end of the transposon was used as sequencing primer. Sequencing data were edited and analysed using the STADEN programs (Staden, 1996). Putative ORFs were screened for similarity to protein sequences in the SWISS-PROT protein sequence database library using the FASTA program (SEQNET facility, Daresbury).

PFGE. PFGE was performed as described by Pattee et al. (1990) using the CHEF-DR II system (Bio-Rad). The CHEF gel was run at $6 \mathrm{~V} \mathrm{~cm}^{-1}$ for $22 \mathrm{~h}$ at $14^{\circ} \mathrm{C}$ with $10-50 \mathrm{~s}$ switching times. Southern blot analysis was performed using a digoxigeninlabelled $8 \mathrm{~kb}$ Sall fragment, which is internal to the Tn917LTV1, as probe (Youngman, 1990).
$\beta$-Galactosidase assays. $\beta$-Galactosidase assays were performed essentially as described by Youngman (1990). Briefly, $0.5 \mathrm{ml}$ aliquots of cells grown in amino-acid- or glucoselimiting CDM were sampled throughout the growth cycle, pelleted $(11000 \mathrm{~g}, 3 \mathrm{~min}, \mathrm{RT})$ and snap frozen at $-70^{\circ} \mathrm{C}$ for later analysis. The frozen cell samples were thawed, lysed in $0.5 \mathrm{ml} \mathrm{AB}$ buffer $\left(100 \mathrm{mM} \mathrm{NaCl}, 60 \mathrm{mM} \mathrm{K} \mathrm{HPO}_{4}, 40 \mathrm{mM}\right.$ $\mathrm{KH}_{2} \mathrm{PO}_{4}$ ) containing $100 \mathrm{ng}$ DNase $\mathrm{ml}^{-1}, 0 \cdot 1 \%$ Triton X-100 and $25 \mu \mathrm{g}$ lysostaphin $\mathrm{ml}^{-1}$. An aliquot $(50 \mu \mathrm{l})$ of each sample was added to $5 \mu \mathrm{l}$ 4-methylumbelliferyl $\beta$-D-galactoside (MUG) solution $\left(0.4 \mathrm{mg} \mathrm{ml}^{-1}\right.$ in $100 \%$ dimethyl sulphoxide) and incubated for $100 \mathrm{~min}$ at $25^{\circ} \mathrm{C}$. The reaction was stopped by addition of $2.5 \mathrm{ml} 0.2 \mathrm{M} \mathrm{Na}_{2} \mathrm{CO}_{3} . \beta$-Galactosidase activity was determined by fluorescence using a DyNA Quant 200 fluorometer (Hoefer Pharmacia Biotech) using a range of concentrations of 4-methylumbelliferone as standard. One MUG unit of $\beta$-galactosidase activity is defined as the activity that hydrolyses 1 pmol MUG $\mathrm{min}^{-1} \mathrm{ml}^{-1}$ per $\mathrm{OD}_{600}$ unit.

\section{RESULTS}

\section{Isolation of stationary-phase survival/recovery mutants}

S. aureus suv mutants were selected using a screen based on their inability to remain culturable as a colony on amino-acid-limiting CDM agar at $25^{\circ} \mathrm{C}$ for $21 \mathrm{~d}$. Approximately 20000 colonies from two independent $S$. aureus 8325-4 transposon libraries were screened using this selection procedure. One hundred and fifty-six putative suv mutants were identified after the first round of screening. These together with the parental strain, $S$. aureus 8325-4, were subjected to a secondary screen under the same limiting conditions to prove their veracity. Twenty suv mutants, designated SPW 1-20, were identified after secondary screening. Liquid starvation-survival assays for all 20 mutants under amino-acid-limiting conditions confirmed their defects. The liquid starvation-survival assays kinetics are shown in Fig. 1 for ten representative mutants which were further characterized. S. aureus $8325-4$ incubated at $25^{\circ} \mathrm{C}$ showed a total loss of viability after $24 \mathrm{~d}\left(>10^{7}\right.$. fold reduction). In contrast, almost all the suv mutants lost culturability between days 11 and 19 (Fig. 1). All mutants showed basically similar stationary-phase survival kinetics.

Phage transduction using phage $\phi 11$ was used to transfer the Tn917-LTV1 insertions into the $S$. aureus 8325-4 parental background. Five transductants from each mutant were tested for their stationary-phase properties against the original mutants and $S$. aureus 8325-4. In all cases, erythromycin-resistant transductants had the defect, indicating that the mutant phenotype is cotransduced with the Tn917-LTV1 insertion (results not shown).

\section{Physical mapping of Tn917-LTV1 insertions on the S. aureus chromosome}

Genomic DNA from each mutant was prepared and digested to completion with $\mathrm{XbaI}$ or EcoRI. Southern blot analysis using a digoxigenin-labelled $8 \mathrm{~kb}$ SalI 

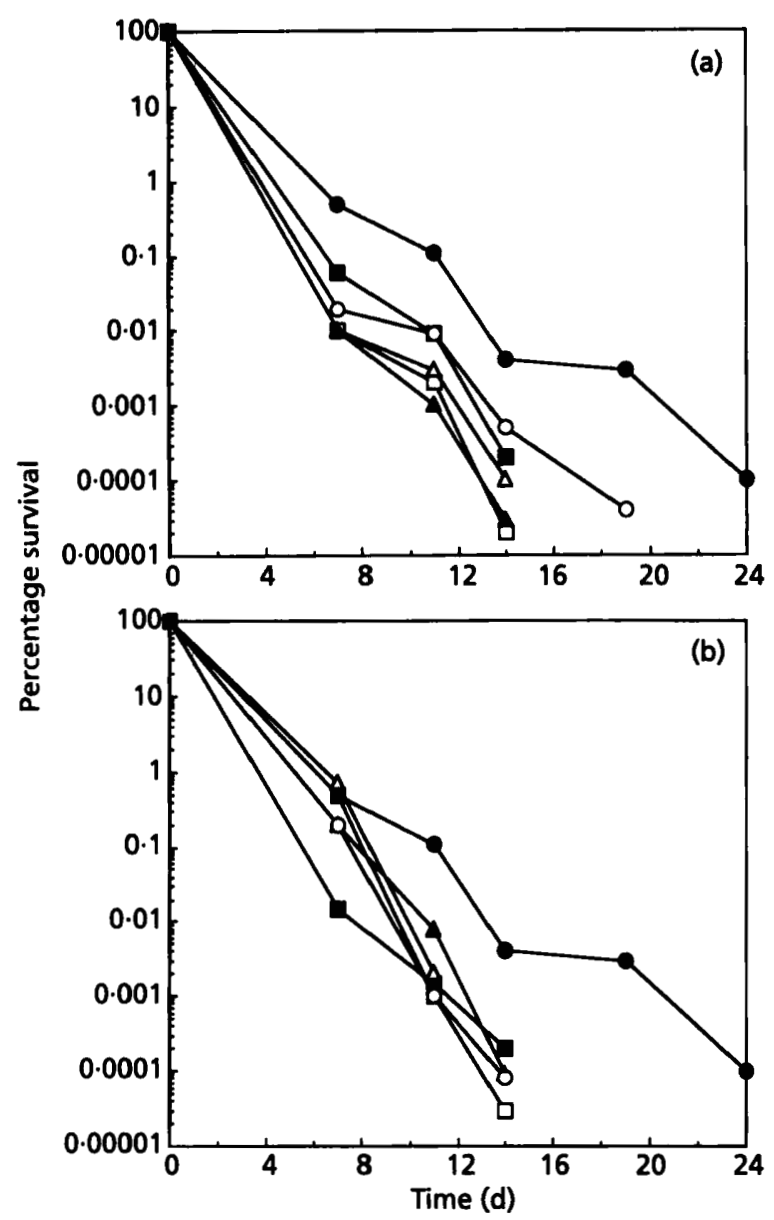

Fig. 1. Stationary-phase survival/recovery kinetics under aminoacid-limiting conditions. (a) S. aureus 8325-4 (O), SPW 1 ( $\square$ ), SPW $2(\triangle)$, SPW $3(\triangle)$, SPW $4(\square)$ and SPW $5(0)$. (b) S. aureus

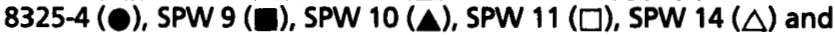
SPW 20 (O). Cultures were grown as described in Methods, then incubated statically at $25^{\circ} \mathrm{C}$. One hundred percent viability corresponds to approximately $5 \times 10^{8}$ c.f.u. $\mathrm{ml}^{-1}$ determined after $18 \mathrm{~h}$ ( $6 \mathrm{~h}$ post-exponential) growth at $37^{\circ} \mathrm{C}$ prior to transfer to $25^{\circ} \mathrm{C}$.

fragment, which is internal to Tn917-LTV1 (Youngman, 1990), gave a single hybridizing band in each mutant (results not shown). This indicates that each mutant had a single Tn917-LTV1 insertion giving rise to the stationary-phase survival/recovery phenotype.

The chromosomal sites of Tn917-LTV1 insertion were physically mapped using PFGE. PFGE of a SmaI restriction digest of the $S$. aureus 8325-4 genome generates 16 fragments ranging in size from 9 to $650 \mathrm{~kb}$ (El-Adhami \& Stewart, 1997). Tn917-LTV1 DNA contains one SmaI restriction site. Therefore, upon restriction digestion of chromosomal DNA of the suv mutants an extra SmaI fragment will be generated as compared to the $S$. aureus $8325-4$ strain. As a consequence, it would be expected that one of the characteristic SmaI fragments of S. aureus 8325-4 would disappear and be replaced by two smaller fragments.
The sum of the two would be equal to the original fragment into which the transposon had inserted, plus the size of Tn917-LTV1 (8 kb).

CHEF analysis mapped the site of insertion of Tn917LTV1 in SPW 1, 2, 9, 11 and 14 to the largest fragment, band $\mathrm{A}(\sim 620 \mathrm{~kb})$ (Fig. 2, Table 1). The combined sizes of the two new resulting fragments were approximately equal to the original size of fragment A (Fig. 2, Table 1). This was confirmed by Southern blotting (results not shown). The transposon insertions in mutants SPW 3,10 and 20 all mapped to band $B(\sim 360 \mathrm{~kb})$ (Fig. 2, Table 1). A $120 \mathrm{~kb}$ fragment was the only distinguishable new band in SPW 3 and the remaining $\sim 270 \mathrm{~kb}$ band overlapped with fragment $E$ as confirmed by Southern blotting (results not shown). SPW 10 and 20 appear to be closely located on fragment $B$ as the resulting fragment sizes appear to be identical (Table 1). However, it is possible that the same size fragments could result from a transposon insertion at either end of the original SmaI fragment. PFGE of SPW 5 and 4 mapped the insertions to fragments $E(\sim 270 \mathrm{~kb})$ and $\mathrm{I}(\sim 120 \mathrm{~kb})$, respectively (Fig. 2, Table 1), as confirmed by Southern blotting (Fig. 2, Table 1 and results not shown).

\section{Stationary-phase survival/recovery properties of the suv mutants}

Phosphate limitation. The stationary-phase survival/ recovery kinetics of the ten $s u v$ mutants were determined under phosphate-limiting CDM conditions, incubated statically, at $25^{\circ} \mathrm{C}$. Only SPW 3 and 20 exhibited reduced plating efficiency compared to $S$. aureus $8325-4$ under phosphate-limiting conditions (results not shown). S. aureus $8325-4$ loses all viability between days 14 and 16 when starved for phosphate $\left(>10^{7}\right.$-fold reduction) compared to between days 8 and 10 for SPW 3 and 20. At day 8, SPW 3 and 20 had 10- and 4-fold lower apparent viability than $S$. aureus $8325-4$, respectively.

Glucose limitation. The stationary-phase survival/ recovery kinetics for the ten suv mutants were determined under glucose-limiting CDM conditions, incubated statically, at $25^{\circ} \mathrm{C}$. Only SPW 3, 11 and 20 exhibited 10 to 100 -fold decreased viability compared with $S$. aureus $8325-4$ after $21 \mathrm{~d}$ of prolonged starvation (Fig. 3).

\section{Resistance to environmental stress}

Hydrogen peroxide. After long-term starvation (4 weeks, $25^{\circ} \mathrm{C}$ ), none of the mutants were any more sensitive to $7.5 \mathrm{mM}$ hydrogen peroxide than the parental strain, $S$. aureus 8325-4 (results not shown).

Acid stress. Long-term starved cells $\left(4\right.$ weeks, $\left.25^{\circ} \mathrm{C}\right)$ were treated with a killing $\mathrm{pH}$ of 2 (Watson et al., 1998) and their viability determined. SPW 1, 3, 4, 9 and 11 all exhibited increased sensitivity to acid treatment compared to the parental strain, S. aureus 8325-4 (Fig. 4). 
(a)

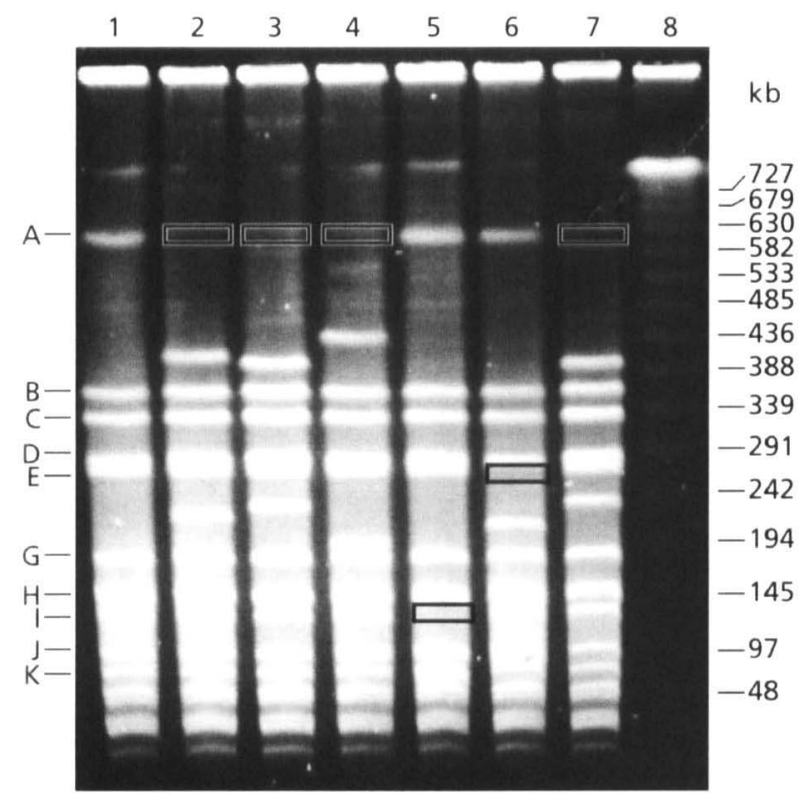

(b)

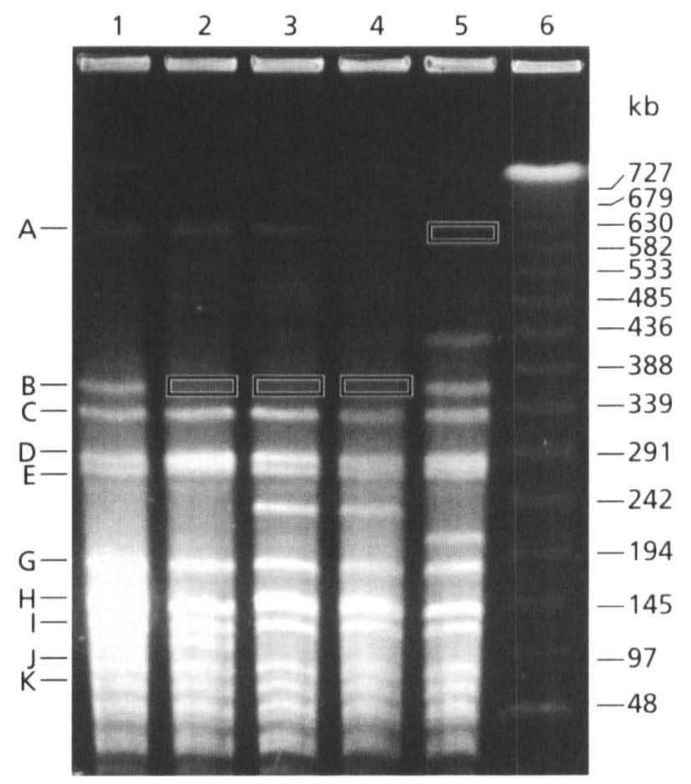

Fig. 2. PFGE separation of Smal-digested genomic DNA from various $S$. aureus suv mutants. (a) Lanes: 1,5 . aureus $8325-4$; 2 , SPW 1; 3, SPW 2; 4, SPW 9; 5, SPW 4; 6, SPW 5; 7, SPW 11; 8, $\lambda$ ladder. (b) Lanes: 1 , S. aureus 8325-4; 2 , SPW 3; 3 , SPW 20; 4, SPW 10;5, SPW 14; $6 \lambda$ ladder. The black boxes highlight the digested fragment compared to $S$. aureus 8325-4.

Table 1. Physical mapping of the Tn917-LTV1 insertion site in sur mutants

All sizes are approximate under the PFGE conditions used.

\begin{tabular}{|lcc|}
\hline Strain & $\begin{array}{c}\text { Smal fragment containing } \\
\text { Tn917-LTV1 (kb) }\end{array}$ & $\begin{array}{c}\text { New fragments } \\
(\mathbf{k b}) \dagger\end{array}$ \\
\hline SPW 1 & A 620 & 410,210 \\
SPW 2 & A 620 & 400,200 \\
SPW 3 & B 360 & 120 \\
SPW 4 & I 120 & 70,60 \\
SPW 5 & E 270 & 225,65 \\
SPW 9 & A 620 & 430,180 \\
SPW 10 & B 360 & 200,145 \\
SPW 11 & A 620 & 400,200 \\
SPW 14 & A 620 & 420,200 \\
SPW 20 & B 360 & 200,145 \\
\hline
\end{tabular}

* Smal fragments missing due to insertion of Tn917-LTV1 and creation of a novel Smal site.

† Two new Smal fragments generated after Tn917-LTV1 insertion as revealed by ethidium bromide staining. The sizes of these fragments were confirmed by Southern blot analysis using the Tn917-LTV1 as probe.

SPW 3 was the most sensitive, being completely killed after only $10 \mathrm{~min}$ treatment.

Table 2 summarizes all the stationary-phase phenotypic studies for the various mutants.

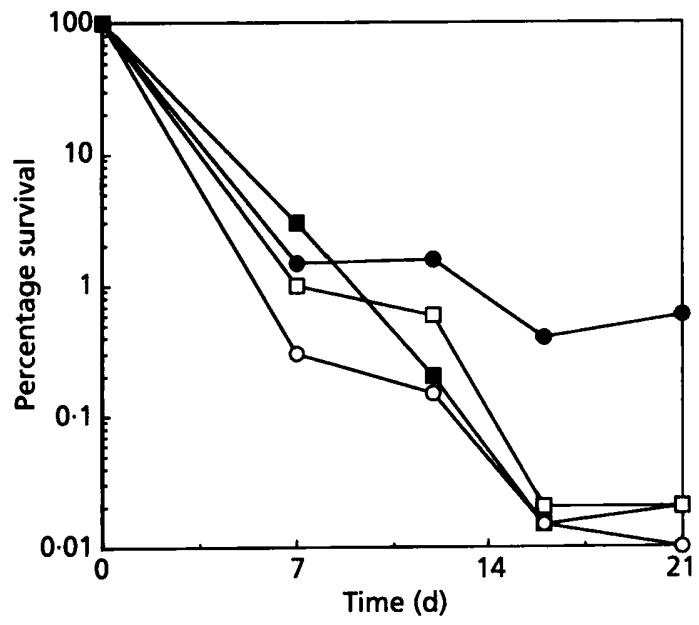

Fig. 3. Stationary-phase survival/recovery kinetics under glucose-limiting conditions. S. aureus 8325-4 (O), SPW $3(\boldsymbol{\square})$, SPW $11(\square)$ and SPW $20(0)$. Cultures were grown as described in Methods, then incubated statically at $25^{\circ} \mathrm{C}$. One hundred percent viability corresponds to approximately $5 \times 10^{8}$ c.f.u. $\mathrm{ml}^{-1}$ determined after $18 \mathrm{~h}$ ( $6 \mathrm{~h}$ post-exponential) growth at $37^{\circ} \mathrm{C}$ prior to transfer to $25^{\circ} \mathrm{C}$.

\section{Expression analysis of Tn917-LTV1 lacZ transcriptional fusions}

Tn917-LTV1 contains a promoterless lacZ gene, so if insertion occurs in the correct orientation downstream of a chromosomal promoter a transcriptional lac $Z$ fusion is created. Initial expression analysis of the ten 


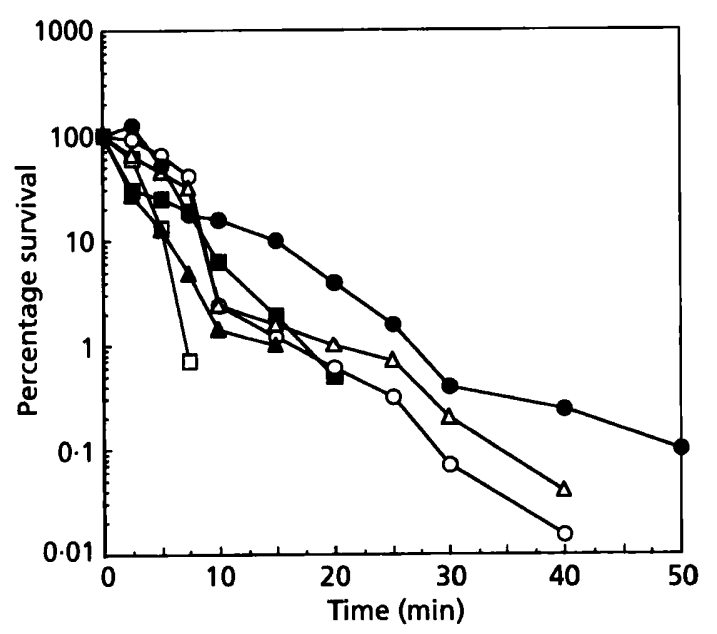

Fig. 4. Acid (pH 2) resistance of the suv mutants. S. aureus $8325-$ 4 (O), SPW 1 ( $\square)$, SPW 3 ( $\square)$, SPW 4 (O), SPW 9 (A) and SPW 11 $(\triangle)$. Cells were starved under glucose-limiting conditions for $28 \mathrm{~d}$ prior to acid treatment as described in Methods. The percentage survival was calculated by plating. One hundred percent viability corresponds to approximately $5 \times 10^{8}$ c.f.u. $\mathrm{ml}^{-1}$. The results are representative of at least two independent experiments.

suv mutants indicated that only three (SPW 3, 4 and 11) had detectable levels of $\beta$-galactosidase activity. SPW 4 exhibited the highest $\beta$-galactosidase activity of approximately 28 and 36 MUG units for amino-acidand glucose-limiting conditions, respectively, during exponential phase. This activity did not increase in stationary phase (Fig. 5a). SPW 3 showed a peak of expression as the cells entered stationary phase of 18 and 25 MUG units for amino-acid- and glucose-limiting conditions, respectively (Fig. 5b). Expression of SPW 11 also showed a stationary-phase peak of 14 and 11 MUG units for amino acid and glucose limitation, respectively (Fig. 5c).

\section{Sequence analysis}

To identify the suv genes, the chromosomal DNA flanking the Tn917-LTV1 insertion sites was rescued. DNA sequence analysis was carried out to determine the nature of the suv genes. Approximately $300 \mathrm{bp}$ of chromosomal DNA sequence proximal to the Tn917LTV1 insertion site for each mutant was generated. Database searches revealed five of the $s u v$ genes to have homology to known sequences which may shed light on their possible roles (Table 3). The mutated genes in SPW $2,5,10,11$ and 20 showed no significant homology to known proteins in the database.

\section{DISCUSSION}

$S$. aureus mutants defective in starvation-induced stationary-phase survival/recovery responses were isolated using a combination of transposon mutagenesis and a screening technique based on the inability of the mutants to remain culturable under amino-acid- and nutrient-limiting conditions. The screen is such that it will identify components important in either long-term survival or recovery as both will result in a reduction in plating efficiency. Southern blot analysis revealed that only one copy of the transposon had inserted into the chromosome of each of the suv mutants. Phage transduction was used to show that in all cases the stationaryphase survival/recovery phenotype was transferred with the Tn917-LTV1 insertion.

All of the mutants isolated had 10- to 100 -fold lower plating efficiency compared to the parental strain, $S$. aureus 8325-4. This observation is in accordance with the drop in viability observed in starvation-induced

Table 2. Summary of stationary-phase survival studies

-, No defect as compared to S. aureus $8325-4$; +, defective as compared to S. aureus 8325-4.

\begin{tabular}{|c|c|c|c|c|c|}
\hline \multirow[t]{2}{*}{ Mutant } & \multicolumn{3}{|c|}{$\begin{array}{l}\text { Survival defect under nutrient } \\
\text { limitation }\end{array}$} & \multicolumn{2}{|c|}{$\begin{array}{l}\text { Environmental stress } \\
\text { resistance }\end{array}$} \\
\hline & Amino acid & Phosphate & Carbon & Acid sensitivity & $\begin{array}{c}\text { Oxidative stress } \\
\text { sensitivity }\end{array}$ \\
\hline $8325-4(\mathrm{WT})$ & - & - & - & - & - \\
\hline SPW $1(s u v-1)$ & + & - & - & + & - \\
\hline SPW $2(s u v-2)$ & + & - & - & - & - \\
\hline SPW $3(s u v-3)$ & + & + & + & + & - \\
\hline SPW $4(s u v-4)$ & + & - & - & + & - \\
\hline SPW $5(s u v-5)$ & + & - & - & - & - \\
\hline SPW 9 (suv-9) & + & - & - & + & - \\
\hline SPW $10(s u v-10)$ & + & - & - & - & - \\
\hline SPW $11(s u v-11)$ & + & - & + & + & - \\
\hline SPW $14(s u \nu-14)$ & + & - & - & - & - \\
\hline SPW $20(s u v-20)$ & + & + & + & + & - \\
\hline
\end{tabular}



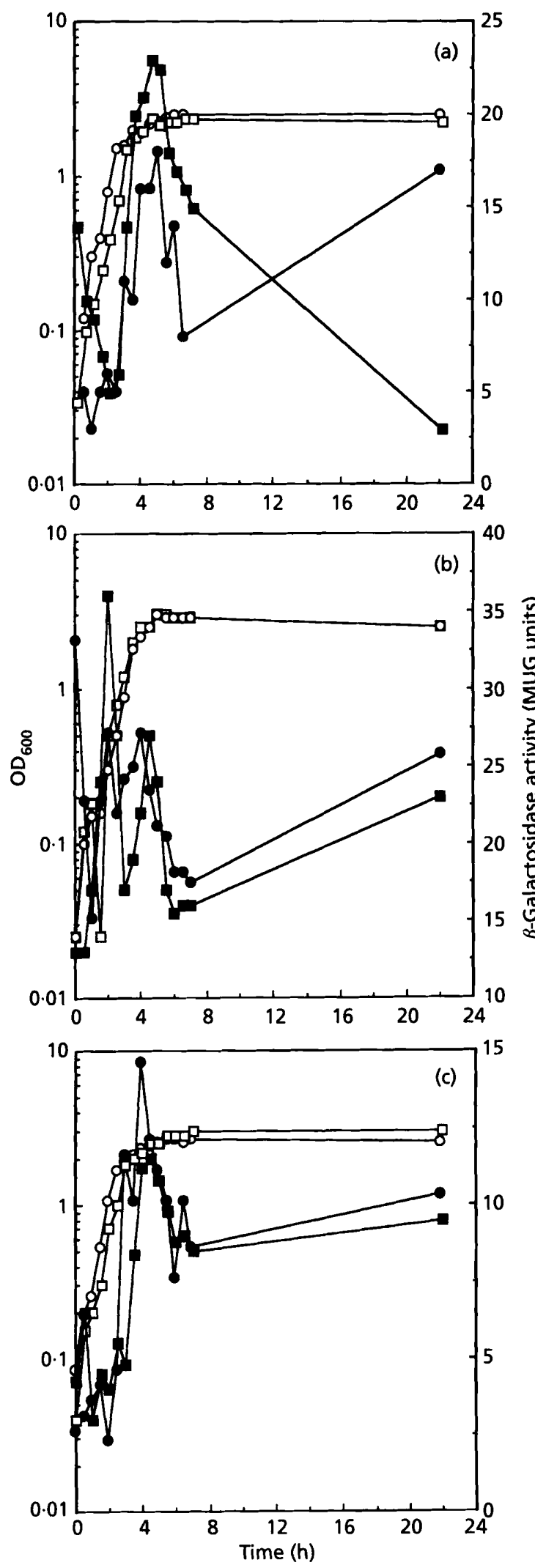

Fig. 5. Expression of suv genes. Strains were grown in CDM limiting for either glucose or amino acids at $37^{\circ} \mathrm{C}$. Growth was determined by $\mathrm{OD}_{600}$ and suv expression by $\beta$-galactosidase activity as described in Methods. (a) SPW 4: $O D_{600}$ in glucoselimiting $\mathrm{CDM}(\square)$ and in amino-acid-limiting CDM $(O) ; \beta$ - stationary-phase survival/recovery mutants isolated in other bacterial species. For example, in Vibrio sp., the starvation-survival mutant $c s r S$ exhibited a 100 -fold lower viability compared to the parental strain after $8 \mathrm{~d}$ of carbon starvation (Ostling et al., 1995). Similarly, in Sal. typhimurium, three mutants designated stiA, stiB and $s t i C$, exhibited 45 - to 70 -fold lower viability than the parent after $20 \mathrm{~d}$ starvation (Spector \& Cubitt, 1992). In E. coli, a mutation in the $p \mathrm{~cm}$ gene, encoding L-isoaspartyl protein methyltransferase, results in a 10 fold drop in viability as compared to the parent after $10 \mathrm{~d}$ of glucose starvation (Li \& Clarke, 1992). In addition, a mutation in the $r p o S$ gene, encoding a sigma factor, exhibits a 100 -fold lower viability than the parent after $8 \mathrm{~d}$ of starvation (Lange \& Hengge-Aronis, 1991).

The suv mutants isolated in this study could be separated into three groups by virtue of their phenotypes (Table 2). Seven of the mutants (SPW 1, 2, 4, 5, 9, 11 and 14) exhibited a defect under amino-acid-limiting conditions alone, one (SPW 11) exhibited reduced plating efficiency during glucose or amino acid starvation and two (SPW 3 and 20) had lowered survival potential when starved under glucose, phosphate or amino-acid-limiting conditions. The $s u v-3$ and $s u v-20$ genes may encode proteins required for maintenance of viability irrespective of the starvation stimulus.

Long-term glucose starvation in $S$. aureus has been shown to elicit a cross-protection to acid stress (Watson et al., 1998). Several of the suv mutants showed increased acid sensitivity after long-term stationary-phase survival. This result is not surprising as the mutants were identified under amino-acid-limiting conditions. The $\mathrm{pH}$ of the supernatant of an amino-acid-limiting medium upon starvation was found to decrease from 7.0 to 5.5 (Watson et al., 1998). This acidification of the medium might contribute to the selection of aciddefective mutants as observed in the six suv mutants. Starvation-associated cross-protection against environmental stress is characteristic of many bacteria and allows the organism to survive environmental assault over a period in which it cannot rapidly adapt (Cheville et al., 1996; Nickerson \& Curtiss, 1997; O’Neal et al., 1994; Seymour et al., 1996; Wilmes-Riesenberg et al., 1997).

Several workers have used lac $Z$ transcriptional fusions to isolate starvation-induced genes and consequently identify starvation-survival and recovery loci (Lange \& Hengge-Aronis, 1991; Spector \& Cubitt, 1992; Uhde et al., 1997). Only three of the suv mutants (SPW 3, 4 and

galactosidase activity in amino-acid-limiting CDM $(O)$ and in glucose-limiting CDM (D). (b) SPW 3, OD ${ }_{600}$ in glucose-limiting CDM $(\square)$ and in amino-acid-limiting $C D M(O) ; \beta$-galactosidase activity in amino-acid-limiting $\operatorname{CDM}(\odot)$ and in glucose-limiting CDM (D). (c) SPW 11, OD 600 in glucose-limiting CDM $(O)$ and in amino-acid-limiting CDM ( $\square)$; $\beta$-galactosidase activity in aminoacid-limiting $\operatorname{CDM}(\boldsymbol{\omega})$ and in glucose-limiting $\operatorname{CDM}(\boldsymbol{O})$. The results are representative of at least two independent experiments. 
Table 3. Homology of the proteins predicted from the primary amino acid sequence and their function

\begin{tabular}{|llllll|}
\hline Mutant & \multicolumn{4}{c|}{ Homology } \\
\cline { 2 - 5 } & \multicolumn{1}{c}{ Species } & Accession no. & Gene & Identity (\%) $)^{*}$ & Homologue \\
\hline SPW 1 & S. epidermidis & X97011 & sodA & 88 & Superoxide dismutase \\
SPW 3 & B. subtilis & P12464 & ctaA & 57 & Haem A synthase \\
SPW 4 & B. subtilis & P12464 & rpoE & 38 & $\delta$-Subunit RNA polymerase \\
SPW 9 & B. subtilis & Z99115 & umuC/samB & 54 & SOS response component \\
SPW 20 & B. subtilis & P37472 & bprT & 55 & Hypoxanthine-guanine \\
& & & & & phosphoribosyltransferase \\
\hline
\end{tabular}

* Refers to the deduced amino acid sequence over a minimum of 54 deduced residues.

11) had the transposon-insertion-derived lac $Z$ in the correct orientation, or expressed it at high enough levels to measure- $\beta$-galactosidase activity. The expression of $s u v-4$ was induced at mid-exponential phase, whereas $s u v-3$ and $s u v-11$ were induced as the cells entered stationary phase. The suv-4 transcriptional fusion exhibited phase 0 loci induction kinetics, whereas the $s u v-3$ and $s u v-20$ exhibited phase 1 loci induction kinetics as observed for starvation-stress response genes in Sal. typhimurium (Spector \& Cubitt, 1992). This correlates with $s u v-3$ and $s u v-11$ playing a role in longterm stationary-phase survival/recovery under both amino acid and glucose limitation.

Analysis of the chromosomal DNA sequence flanking the Tn917-LTV1 insertion sites resulted in the identification of a number of transposon-disrupted ORFs. Comparison of the Suv proteins with sequences in the database demonstrated several similarities to known proteins (Table 3 ).

SPW 4 has a mutation in a gene homologous to $r p o E$ of Bacillus subtilis $(38.5 \%$ over 75 aa). RpoE is the $\delta$ subunit of RNA polymerase which binds to the core enzyme and also its different holoenzyme forms, thereby inhibiting transcription of non-specific templates in $B$. subtilis (Tjian et al., 1977). Recently Desaro et al. (1995) showed that RNA polymerase purified from a $B$. subtilis mutant with an insertion in the $\delta$ gene contains a truncated $\delta$ protein, indicating that the amino-terminal domain is stable in vivo and contains the core-binding function. This suggested that the function of the aminoterminal domain of $\delta$ protein is to bind and orientate the carboxyl-terminal region on the surface of RNA polymerase (Desaro et al., 1995). In SPW 4, the Tn917LTV1 insertion occurred within the putative aminoterminal domain of the $\delta$ protein. Expression analysis of the putative $S$. aureus rpoE: : lac $Z$ transcriptional fusion (strain SPW 4) increased during mid-exponential phase, suggesting that $s u v-4$ may play a regulatory role in stationary phase.

SPW 9 has Tn917-LTV1 inserted in a gene with strong similarity to a protein involved in the SOS response in $B$. subtilis (54\% over 79 aa), designated UmuC, SamB or MucB depending on its origin (Walker, 1995). Exposure to conditions that damage DNA, such as UV-radiation, results in the induction of more than 17 genes, termed the SOS response (Walker, 1984). The $u m u C$ gene is part of the umuCD operon (Shinagawa et al., 1983). Upon SOS induction, UmuC interacts with several proteins, including the post-transcriptionally modified UmuD, the activated form of RecA and DNA polymerase II holoenzyme, such that an error prone repair DNA lesion that normally blocks DNA replication is overcome (Walker, 1995). DNA repair systems are crucial to the viability of long-term starved cells, since a DNA replication blockage will prevent recovery from starvation.

During stationary phase and long-term starvation, nutrient scavenging and salvaging systems are induced. SPW 20 has an insertion in a gene homologous to $h p r T$ from B. subtilis $(55 \%$ over 90 aa). Hypoxanthineguanine phosphoribosyltransferase is a key enzyme in the salvaging system for purine nucleotides. This salvage pathway comprises a collection of enzymes capable of converting nucleobases and nucleosides to nucleotides (Endo et al., 1983; O'Reilly et al., 1984). This enables organisms to use exogenous bases liberated from lysed cells or recycle those produced by the breakdown of unstable RNA. The purine salvage pathway is important during starvation, both as a source of energy and for the maintenance of purine pools. Hypoxanthine is the predominant intracellular nucleobase during stationary phase in E. coli (Rinas et al., 1995). SPW 20 exhibits a stationary-phase survival/recovery defect under glucose, amino acid and phosphate limitation. Thus, suv-20 plays an important role in stationary phase irrespective of the limiting nutrient.

The oxidative stress resistance is important for the survival of $S$. aureus (Watson et al., 1998). Reactive oxygen species cause severe damage to macromolecular cellular components, including RNA, membrane, proteins and most importantly DNA (Fridovich, 1997). One of the defences of the cell against oxidative stress is the synthesis of enzymes, like superoxide dismutase and catalase, that directly destroy reactive oxygen species and thus prevent oxidative damage. The importance of catalase during starvation was highlighted by the initial isolation of the starvation-survival sigma factor, $\sigma^{\mathrm{s}}$, as a 
catalase-deficient mutant (Loewen \& Triggs, 1984). SPW 1 carries an insertion in a gene encoding a protein with a strong similarity to the Mn-SOD family in Staphylococcus epidermidis ( $88 \%$ over 54 aa). Considering the importance of oxidative stress during starvation it is unsurprising that a strain with lowered SOD activity is also a stationary-phase mutant. Three types of SOD have been identified in eubacteria: $\mathrm{Mn}$ SOD (Touati, 1988), Fe-SOD (Yost \& Fridovich, 1973) and Cu-Zn-SOD (Imlay \& Imlay, 1996). A Cu-Zn-SOD has been shown to be necessary for starvation survival in Legionella pneumophila (St. John \& Steinman, 1996).

During starvation, metabolism will alter to reflect nutrient availability and energy requirements of the cell. The use of different terminal oxidases, which are involved in electron transfer, allows the cell to modify its bioenergetics, maximizing energy production in a constantly changing environment. Significant variation in the composition and organization of the B. subtilis electron transport chain is observed in response to the environment. The transposon insertion in SPW 3 inactivated a gene encoding a protein with a strong similarity to CtaA of B. subtilis ( $57 \%$ over $56 \mathrm{aa})$. Deletion of the $c t a A$ gene in $B$. subtilis results in the total lack of membrane $a$-type cytochromes $\left(\mathrm{aa}_{3}\right.$ and $\left.\mathrm{Caa}_{3}\right)$ and an inability to sporulate (Mueller \& Taber, 1989). It is suggested that ctaA encodes a haem A synthase, possibly haem $\mathrm{O}$ monooxygenase and/or deoxygenase (Svensson \& Hederstedt, 1994). The inactivation of the haem biosynthetic enzyme (CtaA) in $S$. aureus might result in the loss of a starvation-specific terminal oxidase. This major disruption of cell metabolism may lead to either a loss of viability during starvation or the inability to recover from stationary phase. As in $B$. subtilis (Van der Oost et al., 1991), expression analysis of the putative $S$. aureus ctaA::lacZ transcriptional fusion (strain SPW 3) showed that ctaA transcription increased at the onset of stationary phase in both aminoacid- and glucose-limiting conditions. This is consistent with SPW 3 being a stationary-phase survival/recovery mutant under amino acid, phosphate and glucose limitation and demonstrates the similarity between CtaA of both B. subtilis and S. aureus.

Recently, Vasilieva et al. (1997) isolated a ctaA mutant of $S$. aureus which shows an increased resistance to cefoxitin, a $\beta$-lactam. This mutant also forms a small colony variant similar to that seen in persistent and antibiotic-resistant $S$. aureus infections (Proctor et al., 1996). S. aureus small colony variants are associated with decreased haemolytic activity ( $\alpha$-toxin), decreased coagulase activity, reduced pigmentation and slow growth. These characteristics allow $S$. aureus small colony variants to persist within host cells and resist antimicrobial agents (Proctor et al., 1996). Whether or not the role of CtaA in systemic infection is enhanced by its stationary-phase survival/recovery attributes remains to be proven.

Our work has identified a number of loci important in stationary-phase survival/recovery of $S$. aureus. Our current research is aimed at determining the molecular basis of the role of these components and how they are regulated during the life cycle of $S$. aureus.

\section{ACKNOWLEDGEMENTS}

This work was supported by the BBSRC (S.P.W. \& M.A.) and the Royal Society (S. J.F.). We are grateful to the BBSRC for the use of the SEQNET facility at Daresbury.

\section{REFERENCES}

Ayliffe, G. A. J. (1997). The progressive intercontinental spread of methicillin-resistant Staphylococcus aureus. Clin Infect Dis 24, 74-79.

Camilli, A., Portnoy, D. A. \& Youngman, P. (1990). Insertional mutagenesis of Listeria monocytogenes with a novel $\operatorname{Tn} 917$ derivative that allows direct cloning of DNA flanking transposon insertions. J Bacteriol 172, 3738-3744.

Cheville, A. M., Arnold, K. W., Buchrieser, C., Cheng, C. M. \& Kaspar, C. W. (1996). rpoS regulation of acid, heat and salt tolerance in Escherichia coli O157:H7. Appl Environ Microbiol 62, 1822-1824.

Clements, M. O. \& Foster, S. J. (1998). Starvation recovery of Staphylococcus aureus 8325-4. Microbiology 144, 1755-1763.

Communicable Disease Report (1994). EMRSA-16 continues to spread. CDR Weekly 4, 1.

Communicable Disease Report (1996). Epidemic methicillinresistant Staphylococcus aureus. CDR Weekly 6, 197.

Desaro, F. J. L., Woody, A. Y. M. \& Helmann, J. D. (1995). Structural analysis of the Bacillus subtilis delta factor: A protein polyanion which displaces RNA from RNA polymerase. $J \mathrm{Mol}$ Biol 252, 189-202.

El-Adhami, W. \& Stewart, P. R. (1997). Genome organisation of Staphylococcus aureus isolates from different populations. J Med Microbiol 46, 297-306.

Endo, T., Uratani, B. \& Freese, E. (1983). Purine salvage pathways of Bacillus subtilis and effect of guanine on growth of GMP reductase mutants. J Bacteriol 155, 169-179.

Fridovich, I. (1997). Superoxide anion radical, superoxide dismutases and related matters. J Biol Chem 272, 18515-18517.

Hussain, M., Hastings, J. G. M. \& White, P. J. (1991). A chemically defined medium for slime production by coagulase-negative staphylococci. J Med Microbiol 34, 143-147.

Imlay, K. R. C. \& Imlay, J. A. (1996). Cloning and analysis of sodC, encoding the copper-zinc superoxide dismutase of Escherichia coli. J Bacteriol 178, 2564-2571.

Jenkins, D. E., Schultz, J. E. \& Matin, A. (1988). Starvation-induced cross protection against heat or hydrogen peroxide challenge in Escherichia coli. J Bacteriol 170, 3910-3914.

Kaprelyants, A. S. \& Kell, D. B. (1993). Dormancy in stationaryphase cultures of Micrococcus luteus: Flow cytometric analysis of starvation and resuscitation. Appl Environ Microbiol 59, 3187-3196.

Kjelleberg, S., Albertson, N., Flardh, K., Holmquist, L., Jouperjaan, A., Marouga, R., Ostling, J., Svenblad, B. \& Weichart, D. (1993). How do non-differentiating bacteria adapt to starvation? Antonie Leeuwenhoek 63, 331-341. 
Lange, R. \& Hengge-Aronis, R. (1991). Identification of a central regulator of stationary-phase gene expression in Escherichia coli. Mol Microbiol 5, 49-59.

Li, C. \& Clarke, S. (1992). A protein methyltransferase specific for altered aspartyl residues is important in Escherichia coli stationary-phase survival and heat-shock resistance. Proc Natl Acad Sci USA 89, 9885-9889.

Lidwell, O. M. \& Lowbury, E. J. (1950). The survival of bacteria in dust. J Hyg 48, 6-43.

Loewen, P. C. \& Triggs, B. L. (1984). Genetic mapping of katF, a locus that with $k a t E$ affects the synthesis of a second catalase species in Escherichia coli. J Bacteriol 160, 668-675.

Mani, N., Tobin, P. \& Jayaswal, R. K. (1993). Isolation and characterisation of autolysis-defective mutants of Staphylococcus aureus created by $\operatorname{Tn} 917-$ lac $Z$ mutagenesis. J Bacteriol 175, 1493-1499.

Maniatis, A. N., Trougakos, I. P., Katsanis, G., Palermons, J., Maniatis, N. A. \& Legakis, N. J. (1997). Changing patterns of bacterial nosocomial infections: A nine year study in a general hospital. Chemotherapy 43, 69-76.

Matin, A., Auger, E. A., Blum, P. H. \& Schultz, J. E. (1989). Genetic basis of stationary-phase survival/recovery in non-differentiating bacteria. Annu Rev Microbiol 43, 293-316.

Mueller, J. P. \& Taber, H. W. (1989). Isolation and sequence of ctaA, a gene required for cytochrome $a a_{3}$ biosynthesis and sporulation in Bacillus subtilis. J Bacteriol 171, 4967-4978.

Nahmias, A. J. \& Shulman, J. A. (1972). Staphylococcal infections: clinical aspects. In The Staphylococci, pp. 483-502. Edited by J. O. Cohen. New York: Wiley.

Nickerson, C. A. \& Curtiss, R. (1997). Role of sigma factor RpoS in initial stages of Salmonella typhimurium infection. Infect Immun 65, 1814-1823.

Novick, R (1967). Properties of a cryptic high-frequency transducing phage in Staphylococcus aureus. Virology 33, 155-166.

Nystrom, T. (1995). Glucose starvation stimulon of Escherichia coli: role of integration host factor in starvation survival and growth phase-dependent protein synthesis. J Bacteriol 177, 5707-5710.

Nystrom, T., Flardh, K. \& Kjelleberg, S. (1990). Responses to multiple-nutrient starvation in marine Vibrio sp. strain CCUG 15956. J Bacteriol 172, 7085-7097.

O'Neal, C. R., Gabriel, W. M., Turk, A. K., Libby, S. J., Fang, F. C. \& Spector, M. P. (1994). RpoS is necessary for both the positive and negative regulation of starvation survival genes during phosphate, carbon and nitrogen starvation in Salmonella typhimurium. J Bacteriol 176, 4610-4616.

O'Reilly, C., Turner, P. D., Smith-Keary, P. F. \& McConnell, D. J. (1984). Molecular cloning of genes involved in purine biosynthetic and salvage pathways of Salmonella typhimurium. Mol Gen Genet 196, 152-157.

Ostling, J., Flardh, K. \& Kjelleberg, S. (1995). Isolation of a carbon starvation regulatory mutant in a marine Vibrio strain. J Bacteriol 177, 6978-6982.

Pattee, P. A., Lee, H.-C. \& Bannantine, J. P. (1990). Genetic and physical mapping of the chromosome of Staphylococcus aureus. In Molecular Biology of the Staphylococci, pp. 41-58. Edited by R. P. Novick. New York: VCH Publishers.

Proctor, R. A., Vesga, O., Otten, M. F., Koo, S. P., Yeaman, M. R., Sahl, H. G. \& Bayer, A. S. (1996). Staphylococcus aureus small colony variants cause persistent and resistant infections. Chemotherapy $42,47-52$.
Reeve, C. A., Amy, P. S. \& Matin, A. (1984). Role of protein synthesis in the survival of carbon-starved Escherichia coli K-12. J Bacteriol 160, 1041-1046.

Rinas, U., Hellmuth, K., Kang, R., Seeger, A. \& Schlieker, H. (1995). Entry of Escherichia coli into stationary-phase is indicated by endogenous and exogenous accumulation of nucleobases. Appl Environ Microbiol 61, 1801-1808.

St. John, G. \& Steinman, H. M. (1996). Periplasmic copper-zinc superoxide dismutase of Legionella pneumophila: role in stationary-phase survival. J Bacteriol 178, 1578-1584.

Sambrook, J., Fritsch, E. F. \& Maniatis, T. (1989). Molecular Cloning: a Laboratory Manual, 2nd edn. Cold Spring Harbor, NY : Cold Spring Harbor Laboratory.

Schenk, S. \& Laddaga, R. A. (1992). Improved methods for electroporation of Staphylococcus aureus. FEMS Microbiol Lett 94, 133-138.

Seymour, R. L., Mishra, P. V., Khan, M. A. \& Spector, M. P. (1996). Essential roles of core starvation-stress response loci in carbonstarvation-inducible cross-resistance and hydrogen peroxideinducible adaptive resistance to oxidative challenge in Salmonella typhimurium. Mol Microbiol 20, 497-505.

Shinagawa, H., Kato, T., Ise, T., Makino, K. \& Nakata, A. (1983). Cloning and characterization of the $u m u$ operon responsible for inducible mutagenesis in Escherichia coli. Gene 23, 167-174.

Spector, M. P. \& Cubitt, C. L. (1992). Starvation-inducible loci of Salmonella typhimurium: regulation and roles in stationaryphase survival/recovery. Mol Microbiol 6, 1467-1476.

Staden, R. (1996). Indexing and using sequence databases. Methods Enzymol 266, 105-114.

Svensson, B. \& Hederstedt, L. (1994). Bacillus subtilis CtaA is a heme-containing membrane protein involved in heme A biosynthesis. J Bacteriol 176, 6663-6671.

Thorne, S. H. \& Williams, H. D. (1997). Adaptation to nutrient starvation in Rhizobium leguminosarum bv. phaseoli: analysis of survival, stress resistance and changes in macromolecular synthesis during entry to and exit from stationary-phase. $J$ Bacteriol 179, 6894-6901.

Tjian, R., Losick, R., Pero, J. \& Hinnenbush, A. (1977). Purification and comparative properties of the delta and sigma subunits of RNA polymerase from Bacillus subtilis. Eur $J$ Biochem 74, 149-154.

Touati, D. (1988). Transcriptional and post-transcriptional regulation of manganese superoxide dismutase biosynthesis in Escherichia coli, studied with operon and protein fusions. J Bacteriol 170, 2511-2520.

Uhde, C., Schmidt, R., Jording, D., Selbitschka, W. \& Puhler, A. (1997). Stationary-phase mutants of Sinorbizobium meliloti are impaired in stationary-phase survival or in recovery to logarithmic growth. J Bacteriol 179, 6432-6440.

Van der Oost, J., Von Wachenfield, C., Hederstedt, L. \& Sarste, M. (1991). Bacillus subtilis cytochrome oxidase mutants : biochemical analysis and genetic evidence for two $a a_{3}$-type oxidases. Mol Microbiol 5, 2063-2072.

Vasilieva, E., Labischinski, H. \& Berger-Bachi, B. (1997). Identification and mapping of new chromosomal sites affecting response to beta-lactams in Staphylococcus aureus. Int $J$ Antimicrob Agents 8, 13-21.

Walker, G. C. (1984). Mutagenesis and inducible responses to deoxyribonucleic acid damage in Escherichia coli. Microbiol Rev 48, 60-93.

Walker, G. C. (1995). SOS-regulated proteins in translesion DNA synthesis and mutagenesis. Trends Biochem Sci 10, 416-420. 
Watson, S. P., Clements, M. O. \& Foster, S. J. (1998). Characterisation of the starvation-survival response of Staphylococcus aureus. J Bacteriol 180, 1750-1758.

Wilmes-Riesenberg, M. R., Foster, J. W. \& Curtiss, R. (1997). An altered rpoS allele contributes to the avirulence of Salmonella typhimurium LT2. Infect Immun 65, 203-210.

Yost, F. J. \& Fridovich, I. (1973). An iron-containing superoxide dismutase from Escherichia coli. J Biol Chem 248, 4905-4908.
Youngman, P. (1990). Use of transposons and integrational vectors for mutagenesis and construction of gene fusions in Bacillus species. In Molecular Biological Methods for Bacillus Species, pp. 221-266. Edited by C. R. Harwood \& S. M. Cutting. New York: Wiley.

Received 9 April 1998; revised 29 June 1998; accepted 9 July 1998. 